Archives of Environmental Contamination and Toxicology

July 2007, Volume 53, Number 1 : Pages 57-65

http://dx.doi.org/10.1007/s00244-006-0046-y

(C) 2007 Springer. Part of Springer Science+Business

Media

The original publication is available at http://www.springerlink.com
Archimer, archive institutionnelle de l'Ifremer http://www. ifremer.fr/docelec/

\title{
Bioaccumulation of Metals in Sediment Elutriates and Their Effects on Growth, Condition Index, and Metallothionein Contents in Oyster Larvae
}

\author{
A. Geffard ${ }^{1,4,}{ }^{*}$, O. Geffard ${ }^{2}$, J.C. Amiard ${ }^{1}$, E. His ${ }^{3}$ and C. Amiard-Triquet ${ }^{1}$ \\ ${ }^{1}$ ISOMer, SMAB, Service d'Ecotoxicologie, 2 rue de la Houssinière, BP 92208, 44322 Cedex 3, Nantes, France \\ ${ }^{2}$ CEMAGREF, Laboratoire d'écotoxicologie, 3 bis Quai Chauveau, 69336 Lyon, France \\ ${ }^{3}$ IFREMER, Quai du Commandant Silhouette, 33120 Arcachon, France \\ ${ }^{4}$ Present address: EA 2069 URVVC, Laboratoire d'EcoToxicologie, Université de Reims Champagne-Ardenne, \\ Faculté des Sciences, Moulin de la Housse, BP 1039, 51687 Reims Cedex, France \\ *: Corresponding author : A. Geffard, email address : alain.geffard@univ-reims.fr
}

\begin{abstract}
:
The bioavailability of $\mathrm{Cd}, \mathrm{Cu}, \mathrm{Zn}$, and $\mathrm{Pb}$ from two metal-contaminated sediments (Bidassoa and Dunkerque) was studied using Crassostrea gigas larvae exposed to sediment elutriates. The metal contents within the sediments, the larvae and larval growth, the condition index, and the induction of metallothionein in the larvae were measured. The larval growth and condition index were only affected after exposure to the highest elutriates concentration (5 to 25\%) from the most contaminated sediment (Dunkerque). Bioaccumulation of all metals was observed in larvae exposed to Dunkerque elutriatre; only $\mathrm{Cu}$ bioaccumulation was observed in the Bidassoa elutriate. The results from larvae exposed to both sediment elutriates show a strong correlation between bioaccumulated metal considered individually or in combination and the metallothionein level in larvae presenting no detrimental effect. On the other hand, in the case of larvae exposed to the highest Dunkerque elutriate concentration and showing the highest metal body burden, we observed a drop in the metallothionein level. These results indicate that metallothionein is a more sensitive indicator of heavy metal pollution than physiological endpoints taken into account in bioassays and could be proposed as an early biomarker of metal exposure in larvae. However, care must be taken with "fault control" due to the toxicological effect on larvae metabolism in the case of substantial contaminant exposure.
\end{abstract}

Keywords: Sediment elutriates - Crassostrea gigas larvae - Larval growth - Metal bioaccumulation Metallothionein 


\section{Introduction}

Marine and coastal areas are constantly subjected to the introduction of natural and anthropogenic pollutants, which are mostly adsorbed by suspended particles and subsequently accumulated in the sediments. Sediments can accumulate metals at concentrations 10,000 times higher than in the overlying water column (Förstner 1979), constituting an important source of contamination and risk for living organisms. Coastal and estuarine areas serve as reproductive and nursery grounds for many invertebrate and fish species and should be preserved.

Benthic and epibenthic species are the most heavily exposed to contaminants originating in sediments, to those which are adsorbed on sedimentary particles as well as to those which are dissolved in interstitial water. Pelagic organisms are also exposed to sediment-bound contaminants either via the food web and/or after the remobilization of contaminants into the sea water (Chapman and Long 1983, Fichet et al. 1998, Miller et al. 2000). The contamination of the water column occurs by diffusion and when the sediments are resuspended by natural factors such as bioturbation (Burgess et al. 1993, Peterson et al. 1996, Ciarelli et al. 1999, 2000), storms, wave and tide action, and by human activities such as dredging operations (Chapman et al. 1998). When sediments are resuspended, the amounts of heavy metals released into the sea water are relatively low (Kwan and Dutka 1996, Van den berg et al. 2001) and do not generally induce short-term toxicity. Long-term toxicity assessment of these low contamination levels requires that sensitive and early-warning biological tools be developed. Elutriate tests can assess the toxicity of sedimentary metals released in the water column when sediments are resuspended (Thompson et al. 1999).

Chemical analyses characterize the contamination level of the medium (water or sediment), but they are inadequate to assess the biological quality of a zone being studied. Only living systems are able to integrate the various complex effects of contaminants that are really bioavailable (Chapman and Long 1983). Numerous bioassays, standardized to varying degrees, have been developed over the two past decades (see Review by Burton 1992; His et al. 1999). Bivalve embryos are among the most sensitive test organisms and have been used in numerous environmental toxicology studies (Taylor 1978, Carr et al. 1996, McPherson and Chapman 2000). Instead of the endpoints considered in bioassays, a larval growth test is most difficult to carry out, but it is more sensitive (Geffard et al. 2002a) and assesses the bioavailability and toxicity of both the soluble contaminant fraction and contaminants adsorbed on suspended particles. Determining the condition index in veligers of Crassostrea gigas was also shown to be a sensitive endpoint (Geffard et al., 2002c).

Bioassays can evaluate the toxicity of contaminants that are really bioavailable and therefore are a valuable tool to study the biological quality of estuaries and coastal areas. However, the physiological endpoints of these tests are not early-warning biological responses. When harmful effects are observed, the biological quality of the area studied is poor and the contamination levels are already high, with consequent irreversible effects on living organisms. Moreover, bioassays do not identify the compounds inducing the observed biological effects.

The bioavailability of contaminants depends on several factors such as the physico-chemical properties of the contaminant itself, the characteristics of the environment and the characteristics of the organism used in the bioassay (Borgmann 2000). One of the recognized methods to assess the bioavailability of contaminants is to observe their accumulation in test organisms. This method takes into account all the factors that control their bioavailability (Connell et al. 1999, Borgmann 2000). Recently, for several compounds, various authors have determined critical body burden concentrations above which biological effects could be observed. However, this approach cannot be used with essential metals $(\mathrm{Cu}, \mathrm{Zn})$ in species which regulate efficiently these elements (Rainbow, 1998) and with PAHs which may be actively biotransformed.

Biomarkers could also be used to study the bioavailability of contaminants, such as metallothionein for metal exposures. Many studies have shown that metallothionein, a low-molecular-weight cytosolic protein, is induced by metal contamination in numerous taxa, including mammals, fish (Hamza-Chaffai et al. 1997) and marine invertebrates (Bebianno and Serafim 1998, Bebianno et al. 2000, Mouneyrac et al. 2000, 2002; see review by Amiard et al., 2006). It is generally admitted that the primary role of metallothionein is the homeostasis of essential metals such as $\mathrm{Cu}$ and $\mathrm{Zn}$, but this protein is also involved in the detoxification of non-essential metals such as Ag, Cd and $\mathrm{Hg}$ (Roesijadi 1992, Amiard et al., 2006). Metallothionein-like protein has also been detected in bivalve larvae of Mytilus galloprovincialis (Pavicic et al. 1994) and Crassostrea virginica (Ringwood and Brouwer 1993, 1995, Roesijadi et al. 1997). However, the inductions are observed for studies using metallic salts and experimental doses that are unrealistic compared to environmental concentrations present even in metal-rich areas. More recently, metallothionein-like protein induction was detected in veligers of $M$. 
galloprovincialis exposed to natural contaminated sediment (Geffard et al. 2002c). However, these authors used freeze-dried sediment known to be more toxic than the fresh sediment (Geffard et al. 2002b, 2004).

The aim of this study was to use several endpoints at different levels of biological organization, namely the larval growth test, the condition index determination and the metallothionein concentration as sensitive and early-warning tools to assess the bioavailability and the toxicity of metals released into the water column when sediments are re-suspended. For this, fertilized eggs and larvae of Crassostrea gigas were exposed to elutriate obtained from natural sediments. Two metal-rich sediments were selected, one from a coastal zone (Bidassoa Estuary, on the French-Spanish border) and the second from the port of Dunkerque (North of France). The final aim of this study was to establish links between biochemical response (metallothionein), metal accumulation, larval growth and the condition index of larvae.

\section{Materials and Methods}

\section{Sampling and preservation of sediment.}

Sediments were sampled in July 1999. At the Bidassoa estuary, only the top $2 \mathrm{~cm}$ of the surface were scraped using a plastic blade. Sediments from the port of Dunkerque were collected with a stainless steel Van Veen grab. All sediments were wet-sieved at $2 \mathrm{~mm}$ to eliminate debris, homogenized and stored in glass bottles at $4^{\circ} \mathrm{C}$ in darkness for less than 1 week prior to bioassays.

Elutriate preparation.

Elutriates were prepared using a modification of Melzian's method (1990). Sediments were shaken mechanically (multi-wrist shaker, $500 \mathrm{rpm}$ ) in filtered seawater (FSW) at a ratio of 1:4 (sediment: water) for $8 \mathrm{~h}$ and allowed to settle for another $8 \mathrm{~h}$ before recovery of the supernatant (elutriate). Elutriate was diluted with FSW to concentrations of 0 (control), 5, 10, 25 and 50\% for Bidassoa sediment and 0 (control), 1, 5, 10 and 25\% for Dunkerque sediment. These concentrations were selected because they did not result in abnormal effects on embryonic development of Crassostrea gigas in previous experiments. The maximum concentrations tested correspond to the no observed effect concentrations (NOEC; Geffard et al. 2002a). An aliquot of each raw elutriate and of the FSW used were used for metal analysis.

\section{Larval rearing.}

Mature oysters were collected in Arcachon Bay (France), which is extensively used for oyster farming based on Pacific oysters Crassostrea gigas and was therefore assumed to have a good biological quality (Geffard et al. 2002b). The procedure to obtain embryos was described in detail by Geffard et al. $(2001 \mathrm{a}, 2002 \mathrm{c})$. Fertilized eggs were counted and placed in 2-I beakers $\left(60,000 \mathrm{I}^{-1}\right)$ filled with the different media to be tested (three replications per treatment). After the first $24 \mathrm{~h}$, veligers maintained in rearing status were placed in $2-I$ beakers $\left(10,000\right.$ larvae $\mathrm{I}^{-1}$, three replications) and fed with Isochrysis galbana (150 algae $\mu l^{-1}$ ). All experimental solutions were renewed at $48-h$ intervals, using elutriates prepared a few hours before. At this time, larvae were photographed with a Canon camera fitted to an inverted microscope and larval height of 50 individuals per replicate (distance between the umbo and the ventral valve margin; Galtsoff 1964) was measured. The growth test was stopped after 10 days for the Bidassoa elutriate. On the contrary, the Dunkerque elutriate had severe effects on $C$. gigas growth, so much so that experiments were stopped on day 5 for the highest concentration and on day 7 for another. In the end, larvae were recovered through a sieve $(32 \mu \mathrm{m})$, rinsed with $0.9 \%$ aqueous ammonium formiate (to eliminate the salt), freeze-dried, weighed and stored at $4^{\circ} \mathrm{C}$ in $\mathrm{a}$ hermetic bag before being used for analysis. The condition index $(\mathrm{Cl})$ of larvae from each replicate was determined using the following equation:

$$
\mathrm{CI}=\frac{\text { mean weight of a lyophilised larvae }(\mu \mathrm{g})}{\text { mean shell height of a larvae }(\mu \mathrm{m})} * 100
$$

\section{Pretreatment of sediments for metal analysis.}

Aliquots (three 0.5-g replicates) of each fresh sediment were taken from the well-homogenized total sample and placed in acid-washed glass tubes. These samples were then dried and weighed to 
determine metal concentration as a function of dry weight. Hot mineralization $\left(95^{\circ} \mathrm{C}\right)$ was performed by adding $5 \mathrm{ml}$ of $\mathrm{HNO}_{3}$ and $3 \mathrm{ml}$ of $\mathrm{HCl}$. This process was conducted until dryness, and the residues were then suspended again in $10 \mathrm{ml}$ of $1 \mathrm{~N} \mathrm{HCl}$ for metal analysis.

\section{Extraction of metals and metallothionein from larvae.}

Geffard et al. (2002c) described the process for tissular compartmentalization of metals and partial purification of metallothionein. Each replication of lyophilized larvae was homogenized in Tris- $\mathrm{NaCl}$ buffer and the cytosolic (S1) and insoluble (P1) fractions were separated by initial centrifugation $\left(25,000 \mathrm{~g}, 55 \mathrm{~min}\right.$ at $\left.4^{\circ} \mathrm{C}\right)$. The insoluble fraction was made up of all cellular and tissular debris plus larva shells. Metallothionein was isolated from an aliquot $(50 \mu \mathrm{l})$ of the $\mathrm{S} 1$ fraction by a second centrifugation $\left(15,000 \mathrm{~g}, 10 \mathrm{~min}\right.$ at $\left.4^{\circ} \mathrm{C}\right)$ after being subjected to heat $\left(75^{\circ} \mathrm{C}, 15 \mathrm{~min}\right)$. This second supernatant (S2) containing metallothionein was frozen at $-80^{\circ} \mathrm{C}$ prior to being used for metallothionein analysis. Before metal analysis, an acid digestion step was required for the soluble (S1) and insoluble (P1) fractions, using a procedure described in Geffard et al. (2002c). After acid digestion, the solutions obtained were supplemented to a known volume $(2 \mathrm{ml})$ with deionized water. The three replications of each exposure condition were treated separately with the exception of the larvae exposed to 5, 10 and $25 \%$ concentrations of the Dunkerque elutriate, where larval growth and weight were low. The three replicate samples were mixed together to prevent problems of sensitivity related to the analytical tools.

Metal assays.

Following the acid digestion phase (for sediment and cytosolic (S1) and insoluble (P1) fraction of larvae), metals were analysed by flame atomic absorption spectrophotometry (AAS) for $\mathrm{Cu}$ in sediment and $\mathrm{Zn}$ in sediment and larva fraction. We used electrothermal AAS with the Zeeman effect (Hitachi Z8200) for $\mathrm{Cu}$ in larvae fractions and for $\mathrm{Cd}$ and $\mathrm{Pb}$ in larva fractions and sediment. The analytical method was previously described by Amiard et al. (1987). To eliminate the matrix effect, standard addition analysis was performed in an iso-medium, and the concentration of each element was $+125,250$ and $500 \mathrm{ng} \mathrm{ml}^{-1}$ for $\mathrm{Zn}$ and $\mathrm{Cu}$ in flame AAS, +12.5, 25 and $50 \mathrm{ng} \mathrm{ml}^{-1}$ for $\mathrm{Cu},+0.25$, $0.50,1 \mathrm{ng} \mathrm{ml}^{-1}$ for $\mathrm{Cd}$, and $6.25,12.5$ and 25 for $\mathrm{Pb}$ in electrothermal AAS. Metal concentrations were determined in the elutriates according to the method described by Danielsson et al. (1982). The assays were validated using certified samples of sediments (SD-M-2/TM IAEA) and mussel tissues (BCR, 278R). The total bioaccumulation of metals ( $\mathrm{Cd}, \mathrm{Cu}, \mathrm{Zn}$ and $\mathrm{Pb}$ ) in larvae was calculated by summing the amounts that were measured in the soluble (S1) and insoluble (P1) fractions.

\section{Larval metallothionein assay.}

The metallothionein assay was performed in the $\mathrm{S} 2$ fraction by differential pulse polarography. The thiol groups (SH) were determined using Brdicka reagent (1933) according to the method of Thompson and Cosson (1984). Measurements were performed at a constant temperature $\left(4^{\circ} \mathrm{C}\right)$ on a polarograph using a PAR Model 174 analyser, a PAR/EG\&G Model 303 electrode in SMDE mode, and a RE0089 type X-Y recorder. The metallothionein amounts were measured by a standard addition using the metallothionein rabbit liver metallothionein standard (Sigma Chemical Co., St Louis, MO, USA) (no metallothionein standard exists for oysters). The validity of this method was confirmed by Olafson and Olsson (1991).

\section{Statistical analysis.}

For each series of results, values were compared by one-way ANOVA (Statistica software). Significant differences (at the 95\% level) were then determined by Tukey's test, except for larvae exposed to 5 , 10 and $25 \%$ of Dunkerque elutriate because there was only one value per elutriate concentration tested.

\section{Results}

Sediment and elutriate contamination 
Metal concentrations in each sample of studied sediments are indicated in Table 1. For comparison, Table 2 gives the French Géode classification system, which defines sediment quality according to the degree of contamination with PCBs and eight metals (Lamy 1996). "Géode background" denotes the natural concentrations and "Géode median" is calculated from the samples taken at various ports in France. Sediments having values lower than double the median (termed "level 1") are authorized for offshore dumping. Sediments with values higher than four times the median (termed "level 2") cannot be dumped offshore. Sediments with intermediate values require further analyses, including bioassays, before a decision is taken. The Dunkerque sediments were more highly contaminated than the Bidassoa sediments. In the sediments from Dunkerque, $\mathrm{Cd}$ and $\mathrm{Zn}$ levels and $\mathrm{Cu}$ and $\mathrm{Pb}$ levels surpassed level 1 and level 2, respectively. Bidassoa sediments were characterized by a $\mathrm{Cu}$ contamination with a value higher than level 1 . Metal concentrations measured in the raw elutriates and control filtered seawater are also presented in Table 1. Inversely to values for sediments, higher metal concentrations were generally observed in elutriate with Bidassoa sediment, except in the case of $\mathrm{Pb}$.

\section{Larval biometry}

The condition index $(\mathrm{Cl})$ of larvae exposed to the Bidassoa elutriate was not significantly different depending on the exposure $(p=0.274 ;$ Table 3$)$. For the Dunkerque elutriate, the $\mathrm{Cl}$ significantly $(p<$ 0.001 ) decreased between the control and the lowest concentration (1\% elutriate). The $\mathrm{Cl}$ of larvae exposed to 5 and $10 \%$ elutriate was lower than of the $\mathrm{Cl}$ of control larvae. The $\mathrm{Cl}$ of larvae exposed to the 25\% Dunkerque elutriate was not indicated because the recovered larvae were only 5 days old.

Bidassoa elutriate induced a weak inhibition of larval growth at the highest concentrations and on day 10 (Fig. 1), but the difference with the control value was not significant $(p=0.07)$. On the contrary, Dunkerque elutriate had harmful effects on $C$. gigas growth (Fig. 1). The growth of larvae reared in $25 \%$ elutriate was significantly reduced $(p<0.001)$ from day 3 to the end of the experiment. The same phenomenon occurred at all concentrations on day $5(p<0.001)$.

\section{Metallothionein concentrations}

For the Bidassoa elutriate, metallothionein contents in larvae significantly increased $(p<0.001)$ for a concentration higher than $5 \%$. Metallothionein values ranged from $864 \mathrm{mg} \mathrm{kg}^{-1}$ for controls to 1,430 $\mathrm{mg} \mathrm{kg}^{-1}$ in larvae exposed to $50 \%$ elutriate (Fig. 2). Metallothionein values were higher by a factor of between 1.2 to 1.7, depending on the degree of contamination. For the Dunkerque elutriate (Fig. 2), the metallothionein concentration significantly increased between the control and the $1 \%$ concentration elutriate $(p<0.05)$, while the concentration rapidly decreased for the highest concentrations. The significance decrease of the metallothionein between the control and the 5, 10 and $25 \%$ concentrations could not be tested because of the lack of replicates. However, metallothionein concentrations in larvae exposed to 5, 10 and 25\% elutriate were three or four times lower than those observed in larvae reared in control sea water and $1 \%$ elutriate. The metallothionein concentration in 7-day-old control larvae (Dunkerque experiment) were significantly lower $(p<0.001)$ than this in 10-day-old control larvae (Bidassoa experiment).

\section{Metal bioaccumulation}

Metal levels of larvae reared in the presence of the different elutriates are showed in Fig. 3 . For the Bidassoa elutriate, no significant $(0.108<p<0.9938)$ bioaccumulations of $\mathrm{Cd}, \mathrm{Zn}$ and $\mathrm{Pb}$ were observed in larvae. Only Cu levels significantly $(p<0.001)$ increased for the elutriate concentration higher than $5 \%$. The $\mathrm{Cu}$ values were higher by a factor of between 1.1 to 1.8 , depending on the degree of contamination. Larvae exposed to Dunkerque elutriate showed contamination levels higher than those exposed to Bidassoa (except in $\mathrm{Zn}$ ). $\mathrm{Cd}$ and $\mathrm{Cu}$ concentrations increased as the elutriate concentration rose. However, the lack of replicates meant that the increase of this significance could not be tested. With $\mathrm{Zn}$ and $\mathrm{Pb}$, significant $(p<0.0108)$ accumulations were observed for the lowest tested concentration (1\%). The metal values were higher by a factor ranging from 1.6 to 2 and 2 to 20 for $\mathrm{Zn}$ and $\mathrm{Pb}$, respectively, depending on the degree of contamination.

Metal concentrations in the cytosolic fractions (S1) (Fig. 4) showed patterns similar to those previously observed in the whole organism ( $1+\mathrm{C} 1)$ (Fig. 3), except for the $\mathrm{Cd}$ at the highest concentration of the Bidassoa elutriate and $\mathrm{Pb}$ for the Dunkerque elutriate. Contrary to what was observed in the whole 
larvae, $\mathrm{Pb}$ concentrations in the cytosolic fraction did not increased consistently according to the degree of exposure.

Metallothionein is a cytosolic heat-stable protein. Consequently, it should be preferable to examine the relationship between metal and metallothionein levels, taking into account metal concentrations in the S2 supernatant obtained after heat denaturation of the cytosol. (However, the fate of metals during heating is questioned, since metal analysis of chromatographic fractions obtained from raw cytosol (S1) and heat-denaturated cytosol (S2) revealed differences in metal binding to cytosol ligands (Bragigand and Berthet, 2003)). Consequently, relationships between metallothionein and S1 metal concentrations were studied. As all studied elements could bind to metallothionein and might therefore contribute concomitantly to metallothionein induction, the relationship between metallothionein and metal levels (S1) was examined, taking into account the metals individually or combined. For relationship studies, all data were taken into account except the highest elutriate concentrations from Dunkerque (5, 10 and 25\%) (Fig. 5), where harmful effects were noted (growth inhibition). Positive and significant relationships were observed for $\mathrm{Cu}, \mathrm{Zn}$ and for all combined elements.

From a biomonitoring point of view and to use metallothionein as a biomarker of metal contamination, metallothionein must reflect the gross metallic concentration. The relationship between total metal $(\mathrm{S} 1+\mathrm{P} 1)$ and metallothionein levels was also examined. Results were similar to those previously observed with cytosolic metal concentrations. Relationships between metal and metallothionein concentrations were significant for $\mathrm{Cu}$ and $\mathrm{Zn}$ and in the case of all elements combined (not shown).

\section{Discussion}

Metals analysis showed that Bidassoa and Dunkerque sediments are heavily contaminated by metals. In comparison with the French Géode classification system, Dunkerque sediment is characterized by $\mathrm{Cu}$ and $\mathrm{Pb}$ contamination and is more contaminated than the Bidassoa sediment, which is only $\mathrm{Cu}$ enriched. Dunkerque sediments are also highly contaminated by polycyclic aromatic hydrocarbons (Geffard et al. 2002b).

The metal contamination of the control sea water was in the same range of magnitude as the metal levels observed in waters from uncontaminated areas (Campanella et al. 2001, Prego and CobeloGarcia 2004) and lower than those of the Gulf of Gaeta, Tyrrhenian Sea (central Italy), known to be slowly contaminated (Conti and Cecchetti 2003). The metal contents of the Bidassoa and Dunkerque elutriates were approximately 10 times more concentrated than the control seawater, with values in the same range of magnitude as metal contaminations currently observed in impacted coastal and estuary areas (RNO 1995, Martino et al. 2002). Cu levels in Bidassoa and Dunkerque elutriates exceeded the environmental quality standard (Matthiessen et al. 1999). According to Slotten and Reuter (1995) and Van den Berg et al. (2001), these results showed that re-suspending sediments induce an increase in the total seawater metal contamination.

Bioavailability of contaminants can be determined using a bioaccumulation test. With Bidassoa elutriates, only the $\mathrm{Cu}$ was bioavailable and accumulated by the larvae. For Dunkerque, all studied metals were bioavailable and accumulated by larvae. Even if highest metal contaminations (the difference between control and exposed larvae) were observed in larvae exposed to the Dunkerque elutriates, the contamination level of exposure for the highest tested concentration (25\%, i.e. $0.019 \mu \mathrm{g}$ $\mathrm{Cd} . \mathrm{I}^{-1}, 1.78 \mu \mathrm{g} \mathrm{Cu} . \mathrm{I}^{-1}, 6.88 \mu \mathrm{g} \mathrm{Zn} . \mathrm{I}^{-1}$ and $3.6 \mu \mathrm{g} \mathrm{Pb} . \mathrm{I}^{-1}$, estimated according to metal concentrations in raw elutriate and control seawater) was lower than the level of Bidassoa elutriates $(50 \%, 0.054 \mu \mathrm{g}$

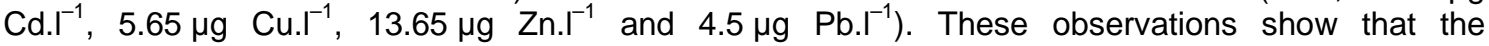
bioavailability of metals from the Dunkerque elutriates was higher than those from the Bidassoa elutriates. This difference could be due to several parameters influencing metal bioavailability such as dissolved organic carbon or total suspended solids. These parameters were not available for this study, but a previous study using sediments sampled at the same sites indicated differences in the size of particles constituting the major part of sediment, dissolved organic carbon and suspended particulate matter in the elutriates (Geffard et al., 2002b; Geffard et al., 2004). According to Fichet et al. (1998) and Geffard et al. (2002a), parts of the heavy metals released in the water, when sediments are re-suspended, and/or are bioavailable, could be accumulated and toxic. According to Borgmann (2000), the contamination level in larvae is a better indicator of a potential biological impact than the contamination levels of the medium.

In our previous study (Geffard et al. 2002a), the Bidassoa and Dunkerque elutriates had no effect on C. gigas embryogenesis at $50 \%$ and $25 \%$ concentrations, respectively. the $50 \%$ Bidassoa elutriate concentration did not induce deleterious effects on the growth and condition index of larvae, after a 
10-day exposure. On the contrary, with the Dunkerque elutriate, the larval growth test was much more sensitive than the embryotoxicity test. Growth and $\mathrm{Cl}$ inhibition were observed at the lowest elutriate concentration (1\%). These results are in agreement with those of His et al. (1999) who found that larval growth is the most sensitive life stage in this organism. The decrease in the $\mathrm{Cl}$ indicates that in exposed larvae, the inhibition of weight was greater than the inhibition of height. The $\mathrm{Cl}$ is an interesting and early warning marker of contaminant effects on larvae. These observations show that released sediment-bound contaminants may affect the physiology and metabolism of oyster larvae. The resuspension of sediments constitutes a great risk for pelagic species.

The larval growth test in $C$. gigas is a sensitive bioassay and can assess the toxicity of bioavailable contaminants, a useful tool to study the biological quality of sediments. However, they cannot identify the compounds inducing the observed biological effects.

The metallothionein level in larvae exposed to the Bidassoa elutriates increased as the degree of contamination rose. Metallothionein is thought to be produced in response to increased intracellular levels of free metal to prevent or reverse potentially detrimental, nonspecific binding of metals to other ligands (Roesijadi et al. 1996). These observations confirm that released metals from the Bidassoa sediment were really bioavailable. Ringwood and Brower $(1993,1995)$ and Roesijadi et al. (1996) have also showed metallothionein inductions in C. gigas larvae exposed to metallic salts under laboratory conditions. However, they found that the first induction occurred at a $\mathrm{Cd}$ concentration of $0.6 \mu \mathrm{g} . \mathrm{I}^{-1}$, which is 30 -fold higher than the $10 \%$ Bidassoa elutriate concentrations $\left(0.018 \mu \mathrm{g} \mathrm{Cd} . \mathrm{I}^{-1}\right)$ that resulted in a significant metallothionein induction in this study. The early timing of the metallothionein response to metal bioaccumulation, according to the degree of exposure, compared to the responses of other physiological endpoints taken into account in this study (growth and $\mathrm{Cl}$ ), make it possible to define a scale of sensitivity of biological and biochemical responses in C. gigas larvae:

Metallothionein>larval growth $=\mathrm{Cl}>$ abnormal embryogenesis

Similar observations were made by several authors in another bivalve species, Mytilus galloprovincialis (Pavicic et al. 1994, Geffard et al. 2002c).

For the Dunkerque elutriates, metallothionein levels slowly increased between the control and the 1\% elutriate concentration, and then sharply decreased. These observations could be explained by the poor physiological state of larvae (the condition index and growth lower than controls). These results are good examples of a situation which has been referred to as spillover (Brown and Parsons 1978), the saturation of detoxification mechanisms, producing the first harmful effects. This phenomenon has been described in several species in laboratory: fish Pleuronecta platessa (Georges and Olsson 1994), copepods, Tigriopus brevicornis (Barka et al. 2001) and bivalve larvae, Mytilus galloprovincialis (Geffard et al. 2002c).

According to earlier results and the good relationships observed between the most highly bioaccumulated metals $(\mathrm{Cu}$ and $\mathrm{Zn})$ and metallothionein, the concentrations indicated that the metallothionein level reflects: 1) the cytosolic metal load was the highest in toxicological terms (Wallace et al. 2003) and 2) the gross metallic concentrations (S1+P1) suggested its possible use as a metal exposure biomarker. The absence of a relationship between metallothionein and cadmium concentrations could be explained by the very low bioaccumulation of this metal by larvae. Concerning lead, the total bioaccumulated metal due to elutriate exposure was found in the insoluble fraction (P1), suggesting a low involvement of metallothionein in the detoxification of this element as well as a low induction of metallothionein synthesis by lead. As shown with other species (Mytilus edulis larvae, Geffard et al. 2002c), oyster larvae could be used as a biological matrix to determine metallothionein as a biomarker of metallic pollution. The greatest advantage of using the larva stage of the bivalve as a biological matrix compared to the adult stage stems from the higher sensitivity of this stage to different contaminant families (His et al. 1999). The potential use of metallothionein as a biomarker in bivalve larvae in biomonitoring programs could be determined during in situ tests as developed by Geffard et al. (2001b).

Larvae exposed to the highest Dunkerque elutriate concentrations (5, 10 and 25\%) had the highest metal body burden and corresponded to the lowest metallothionein level. These individuals constitute "fault controls" not due to low levels of contaminant exposure, but inversely to very high levels of contaminant exposure, which induce detrimental effects and the spillover phenomenon, as described above. In biomonitoring programs, in order to avoid these fault controls, it is important to use several biochemical biomarkers that are more or less specific to a contaminant family, as proposed by several authors (Narbonne et al. 1999, de Lafontaine et al. 2000, Cajaraville et al. 2000), including easily measured global physiological markers such as the condition index.

These results showed that Dunkerque sediments are a biological hazard when they are re-suspended (e.g. dredging). Moreover, the present study, using metal concentrations similar to those found in 
natural environments, showed an early (low-dose) metallothionein response as compared to the time that abnormalities appeared. Thus, the determination of metallothionein in oyster larvae could be used as a biomarker of metal exposure, an important ecological factor because successful breeding is necessary to maintain the population.

\section{Acknowledgements}

The authors would like to thank Linda Northrup for her careful English revision of manuscript.

\section{LITERATURE CITED}

Amiard JC, Pineau A, Boiteau HL, Métayer C, Amiard-Triquet C (1987) Application de la spectrométrie d'absorption atomique Zeeman aux dosages de huit éléments traces ( $\mathrm{Ag}, \mathrm{Cd}, \mathrm{Cr}, \mathrm{Cu}, \mathrm{Mn}, \mathrm{Ni}, \mathrm{Pb}$ et Se) dans les matrices biologiques solides. Wat Res 21: 693-697

Amiard JC, Amiard-Triquet C, Barka S, Pellerin J, Rainbow PS (2006) Metallothioneins in aquatic invertebrates : their role in metal detoxication and their use as biomarkers. Aquat Toxicol 76: 160-202

Barka S, Pavillon JF, Amiard JC (2001) Influence of different essential and non-essential metals on MTLP levels in the copepod Tigriopus brevicornis. Comp Biochem Physiol 128C: 479-493

Bebianno MJ, Serafim MA (1998) Comparison of metallothionein induction in response to cadmium in the gills of the bivalve molluscs Mytilus galloprovincialis and Ruditapes decussates. Sci Total Environ 214:123-131

Bebianno MJ, Serafim MA, Simes D (2000) Metallothioneins in the clam Ruditapes decussatus: an overview. Analusis 28:386-390

Borgmann U (2000) Methods for assessing the toxicological significance of metals in aquatic ecosystems: bio-accumulation-toxicity relationships, water concentrations and sediment spiking approaches. Aquat Ecosystem Health Manag 3: 277-289

Brdicka A (1933) Polarographic studies with the dropping mercury method. A new test for proteins in the presence of cobalt salts in ammoniacal solution of ammonium chloride. Collect Czech Chem Commun 5:112-128

Bragigand V, Berthet B (2003) Some methodological aspects of metallothionein evaluation. Comp Biochem Physiol 134A:55-61

Brown DA, Parsons TR (1978) Relationship between cytoplasmic distribution of mercury and toxic effects to zooplancton and chum salmon (Oncorhynchus keta) exposed to mercury in a controlled ecosystem. J Fish Res Board Can 35: 880-884

Burgess RM, Schweitzer KA, McKinney RA, Phelps DK (1993) Contaminated marine sediment : water column and interstitial toxic effect. Environ Toxicol Chem 12:127-138

Burton GA (1992) Sediment toxicity assessment. Lewis Publishers, London

Cajaraville MP, Bebianno MJ, Blasco Jporte C, Sarasquete C, Viarengo A (2000) The use of biomarkers to assess th eimpact of pollution in coastal environments of the Iberian Peninsula: a pratical approach. Sci Tot Environ 247: 295-311

Campanella L, Conti ME, Cubadda F, Sucapane C (2001) Trace metals in seagrass, algae and molluscs from an uncontaminated area in the Mediterranean. Environ Poll 111:117-126

Carr RS, Chapman DC, Howard CL, Biedenbach J (1996) Sediment Quality Triad assessment survey in Galvestone Bay, Texas system. Ecotoxicology 5:1-25

Chapman PM, Long ER (1983) The use of bioassays as part of a comprehensive approach to marine pollution assessment. Mar Poll Bull 14: 81-84

Chapman PM, Wang F, Janssen C, Persoone G, Allen HE (1998) Ecotoxicology of metals in aquatic sediments: binding and release, bioavailability, risk assessment, and remediation. Can J fish Aquat Sci 55:2212-2243

Ciarelli S, Kater BJ, van Straalen NM (2000) Influence of bioturbation by the amphipod Corophium volutator on fluoranthene uptake in the marine polychaete Nereis virens. Environ Toxicol Chem 19:1575-1581 
Ciarelli S, Van Straalen NM, Klap VA, Van Wezel AP (1999) Effects of sediment bioturbation by estuarine amphipod Corophium volutator on fluoanthene resuspension and transfert into the mussel (Mytilus edulis). Environ Toxicol Chem 18:218-328

Connell DW, Chaisuksant Y, Yu J (1999) Importance of Internal Biotic Concentrations in Risk evaluations with Aquatic Systems. Mar Pollut Bull 39:54-61

Conti ME, Ceccheti G (2003) A biomonitoring study: trace metals in algae and molluscs from Tyrrhenian coastal areas. Environ Res 93:99-112

Danielsson LG, Magnusson B, Westerlund S, Zhang K (1982) Trace metal determination in estuarine waters by electrothermal atomis absorption spectrometry after extraction of dithiocarbamatecomplexes into Freon. Anal Chim Acta 144: 183-188

Fichet D, Radenac G, Miramand P (1998) Experimental studies of impacts of harbour sediment resuspension on marine invertebrate larvae: Bioavailability of $\mathrm{Cd}, \mathrm{Cu}, \mathrm{Pb}$ and $\mathrm{Zn}$ and toxicity. Mar Poll Bull 36: 509-518

Förstner U (1979) Metal pollution assessment from sediment analysis. In: Förstner U, Witmann GTW (eds) Metal pollution in the aquatic environment. Springer-Verlag, New York, p 110-196

Galtsoff PS (1964) The American oyster, Crassostrea virginica Gmelin. U S Fish and Wildlife Service, Fishery Bulletin 64

Geffard O, Budzinski H, Augagneur S, Seaman MNL, His E (2001a) Assessment of sediment contamination by spermiotoxicity and embryotoxicity bioassays with sea urchins (Paracentrotus lividus) and oysters (Crassostrea gigas). Environ Toxicol Chem 20:1606-1611

Geffard O, His E, Budzinski H, Seaman M, Garrigues P (2001b) Qualité biologique de l'eau de mer évaluée in situ par le test embryo-larvaire de Crassostrea gigas et Mytilus galloprovincialis. C R Acad Sci Paris 324:1149-1155

Geffard O, Budzinski H, His E (2002a) The effects of elutriates from PAH and heavy metal polluted sediments on Crassostrea gigas (Thunberg) embryogenesis, larval growth and bio-accumulation by the larvae of pollutants from sedimentary origin. Ecotoxicology 11: 403-416

Geffard O, Budzinski H, His E, Seaman MNL, Garrigues P (2002b) Relationships between contaminant levels in marine sediments and their biological effects upon embryos of oysters, Crassostrea gigas. Environ Toxicol Chem 21: 2310-2318

Geffard A, Geffard O, His E, Amiard, JC (2002c) Relationships between metal bioaccumulation and metallothionein levels in larvae of Mytilus galloprovincialis exposed to contaminated estuarine sediment elutriate. Mar Ecol Prog Ser 233: 131-142

Geffard O, His E, Budzinski H, Chiffoleau, Coynel A, Etcheber H (2004) Effects of storage method and duration on the toxicity of marine sediments to embryos of oyters Crassostrea gigas. Environ Poll 129:457-465

George SG, Olsson PE (1994) Metallothioneins as indicators of trace metal pollution. In: Kramer KJM (ed), Biomonitoring of Coastal Waters and Estuaries. CRC Press, Boca Raton, p 151-178

Hamza-Chaffai A, Amiard-Triquet C, El Abed A (1997) Metallothionein-like protein: it is an efficient biomarker of metal contamination? A case study based on fish from the Tunisian coast. Arch Environ Contam Toxicol 33:53-62

His E, Beiras R, Seaman MNL (1999) The assessment of aquatic contamination: bioassays with bivalve embryos and larvae. Ad Mar Biol 37: 1-178

Kwan KK, Dukta BJ (1996) Development of reference sediment samples for solid phase toxicity screening tests. Bull environ Contam Toxicol 56:696-702

Lafontaine de Y, Gagné F, Blaise C, Costan G, Gagnon P, Chan HM (2000) Biomarkers in zebra mussels (Dreissena polymorpha) for the assessment and monitoring of water quality of the St Lawrence River (Canada). Aquat Toxicol 50 : 51-71

Lamy Environnement (1996) Eaux marines - Pollutions par immersion, Section II : Dispositions prises sur le plan national, Sous Section II : Normes de rejets.- 53062 - L'eau - (C) Lamy S.A. - Décembre 1996

Martino M, Turner A, Nimmo M, Millward GE (2002) Resuspension, reactivity and recycling of trace metals in the Mersey Estuary, UK. Mar Chem 77:171-186

Matthiessen P, Reed J, Johnson M (1999) Sources and Potential Effects of Copper and Zinc Concentrations in the Estuarine Waters of Essex and Suffolk, United Kingdom. Mar Pollut Bull 38: 908-920

McPherson CA, Chapman PM (2000) Copper effects on potential sediment test organisms: the importance of appropriate sensitivity. Mar Pollut Bull 40:656-665

Melzian BD (1990) Toxicity assessment of dredged materials: acute and chronic toxicity as determined by bioassays and bioaccumulation tests. In: Alzieu C, Gallenne B (eds) Proceedings of the International Seminar on Environmental Aspects of Dredging Activities. Goubault Imprimeur, Nantes 
Miller BS, Pine DJ, Redshaw CJ (2000) An assessment of the contamination and toxicity of marine sediments in the Holy Loch, Scotland. Mar Poll Bull 40: 22-34

Mouneyrac C, Geffard A, Amiard JC, Amiard-Triquet C (2000) Metallothionein-like proteins in Macoma balthica : effects of metal exposure and naturals factors. Can J Fish Aquat Sci 57:34-42

Mouneyrac C, Amiard JC, Amiard-Triquet C, Cottier A, Rainbow PS, Smith BD (2002) Partitioning and accumulated trace metals in the talitrid amphipod crustacean Orchestia gammarelus: a cautionary tale on use of metallothionein-like proteins as biomarkers. Aquat Toxicol 57:225-242

Narbonne JF, Daubèze M, Clérandeau C, Garrigues P (1999) Scale of classification based on biochemical markers in mussels: application to pollution monitoring in European coasts. Biomarkers 4: $415-424$

Olafson RW, Olsson PE (1991) Electrochemical detection of metallothionein. Meth Enzymo 205: 205213

Pavicic J, Skreblin M, Kregar I, Tusek-Znidaric M, Stegnar P (1994) Embryo-larval tolerance of Mytilus galloprovincialis, exposed to elevated seawater metal concentrations-1. Toxic effects of $\mathrm{Cd}, \mathrm{Zn}$ and $\mathrm{Hg}$ in relation to the metallothionein level. Comp Biochem Physiol 107:249-257

Peterson GS, Ankley GT, Leonard EN (1996) Effects of bioturbation on metal-sulfide oxidation in surficial freshwater sediments. Environ Toxicol Chem 15:2147-2155

Prego R, Cobelo-Garcia A (2004) Cadmium, copper and lead contamination of the seawater column on the Prestige Shipwreck (NE Atlantic Ocean). Anal Chim Acta :23-26

Rainbow PS, 1998. Phylogeny of trace metal accumulation in crustaceans. In : Langston WJ, Bebianno MJ (eds) Metal metabolism in aquatic environment. Chapman \& Hall, London, p 285-319

Ringwood AH, Brouwer M (1993) Expression of constitutive and metal-inducible metallothioneins in oyster embryos (Crassostrea virginica). Comp Biochem Physiol 106B: 523-529

Ringwood AH, Brouwer M (1995) Patterns of metalloprotein expression in oyster embryos. Mar Environ Res 39: 101-105

R.N.O (1995) Surveillance du milieu marin. Travaux du R.N.O, IFREMER, Edition 1995

Roesijadi G (1992) Metallothionein in metal regulation and toxicity in aquatic animals. Aquat Toxico 22: $81-114$

Roesijadi G, Hansen KM, Unger ME (1996) Cadmium-induced metallothionein expression during embryonic and early larval development of the mollusc Crassostrea virginica. Toxicol Appl Pharmacol 140: 356-363

Roesijadi G, Hansen KM, Unger M. (1997) Concentration-response relationships for $\mathrm{Cd}$, $\mathrm{Cu}$, and $\mathrm{Zn}$ and metallothionein mRNA induction in larvae of Crassostrea virginica. Comp Biochem Physiol118C: 267-270

Slotten DG, Reuter JE (1995) Heavy metals in intact and resuspended sediments of a Califronia reservoir, with emphasis on potential bioavailability of copper and zinc. Mar Freshwater Res 46:257265

Taylor D (1978) A summary of the data on the toxicity of various materials to aquatic life. 5. Copper. Imperial. Chem. Industries. Rapport BL/A/1900, 21p

Thompson B, Anderson B, Hunt J, Taberski K, Philips B (1999) Relationship between sediment contamination and toxicity in San Francisco Bay. Mar Environ Res 48:285-310

Thompson JAJ, Cosson RP (1984) An improved electrochemical method for the quantification of metallothionein in marine organisms. Mar Environ Res 11: 137-152

Van Den Berg GA, Meijers GGA, Van Der Heijdt LM, Zwolsman JG (2001) Dredging-related mobilisation of trace metals: a case study in the Netherlands. Wat Res 35: 1979-1986

Wallace WG, Lee BG, Luoma SN (2003) Subcellular compartmentalization of Cd and Zn in two bivalves. I. Significance of metal-sensitive fractions (MSF) and biologically detoxified metal (BDM). Mar Ecol Prog Ser 249:183-197 


\section{Figures}

Figure 1
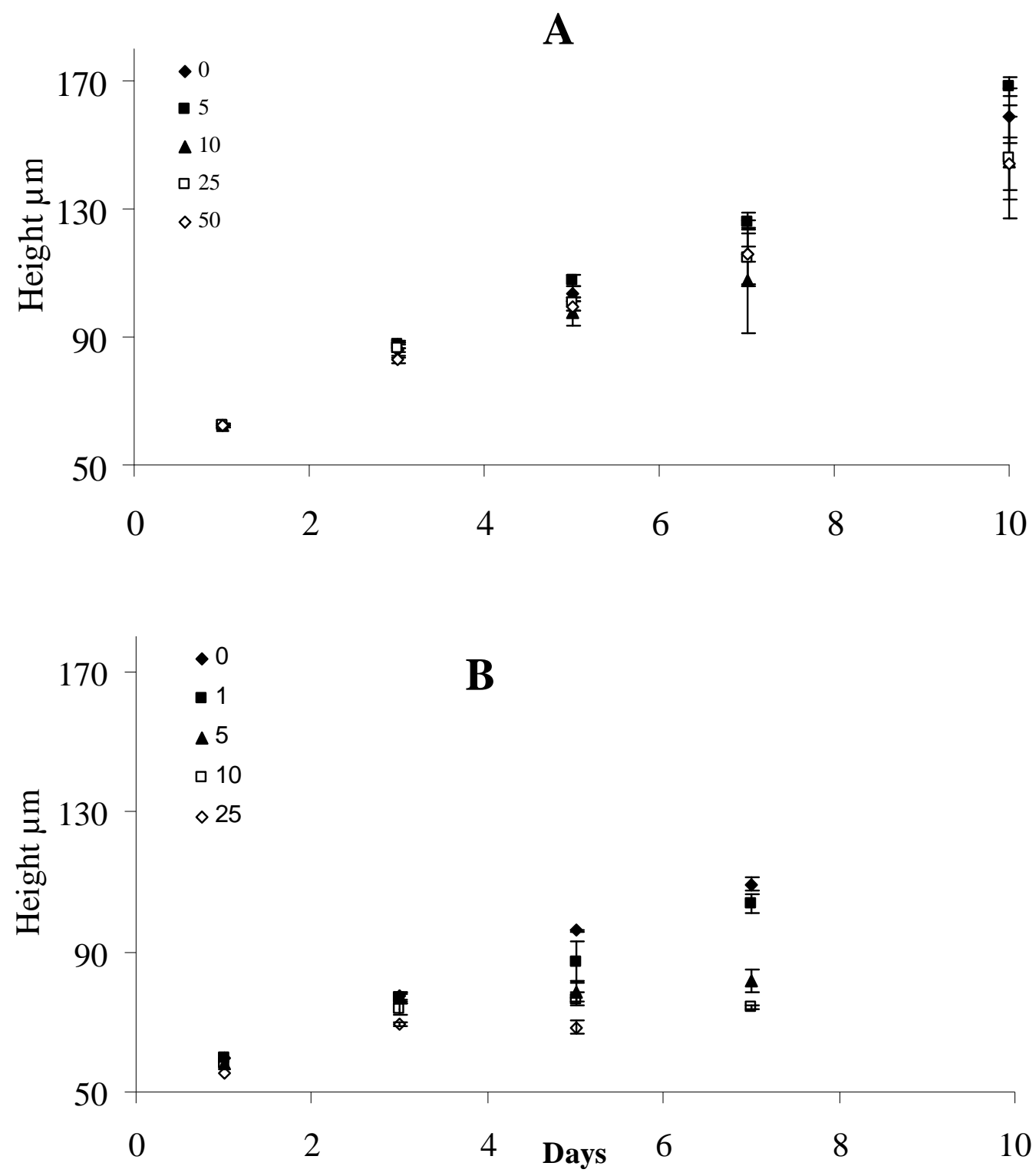

Figure 1: Growth ( $\mu \mathrm{m}$; mean $\pm \mathrm{SD}$ ) of Crassostrea gigas larvae exposed to Bidassoa $(\mathrm{A})$ and Dunkerque elutriates (B) for 10 and 7 days, respectively. Statistical comparison is presented in the text. 
Figure 2

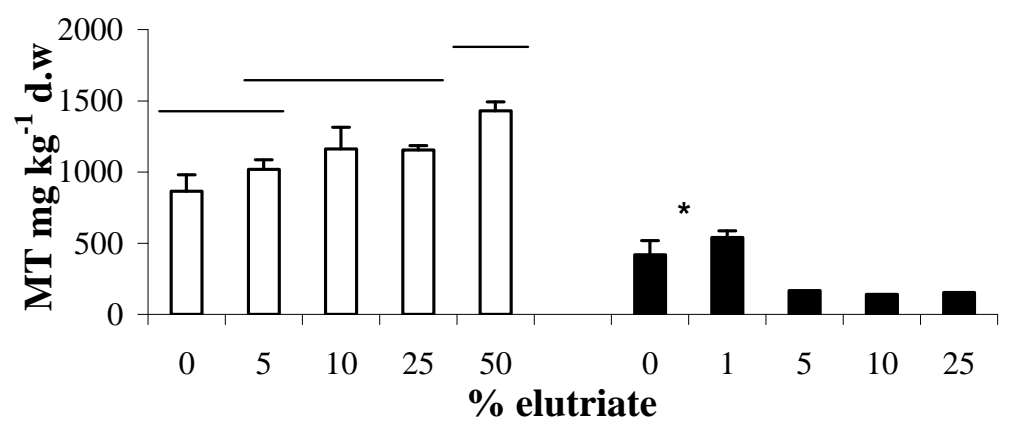

Figure 2: Metallothionein contents (mean $\pm \mathrm{SD}, \mathrm{n}=3$ ) in larvae after 10 days (Bidassoa, white bars) or 7 days (Dunkerque, black bars, except at 25\% only 5 days) of exposure to different elutriate concentrations. For Bidassoa, values not significantly different from each other are grouped under a common overhead line (ANOVA, $p<0.05$; Scheffé's test). For Dunkerque only control larvae and larvae exposed to $1 \%$ of elutriate could be compared (see text) * indicate a significant difference at the $95 \%$ level of significance. 

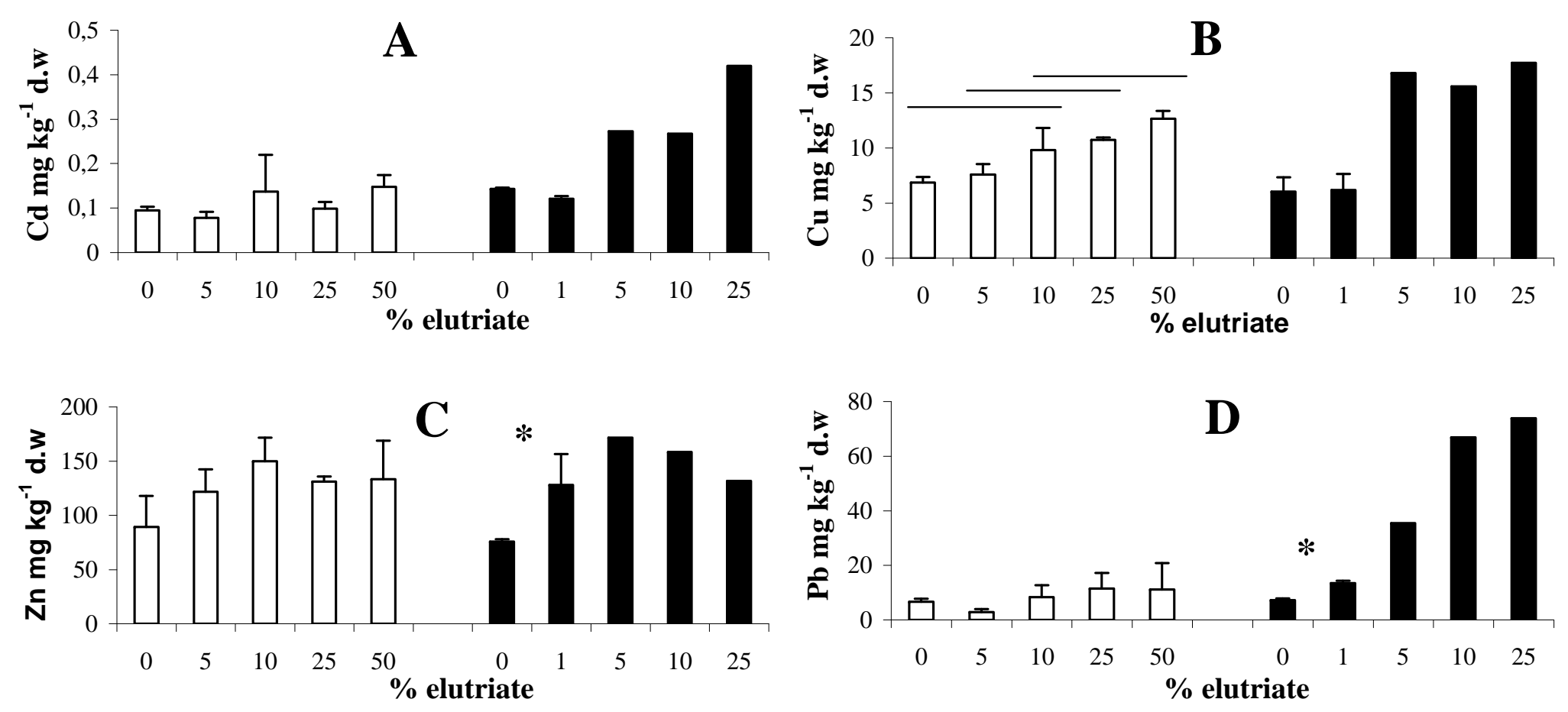

Figure 3. Total metal concentrations (mean $\pm \mathrm{SD}$, three replications) in larvae after 10 days (Bidassoa, white bars) or 7 days (Dunkerque, black bars; except at $25 \%$ only 5 days) of exposure to different elutriate concentrations. A, Cd; B, Cu; C, Zn and D, Pb. For statistical comparison presentation, see Figure 2 legend. 
Figure 4:
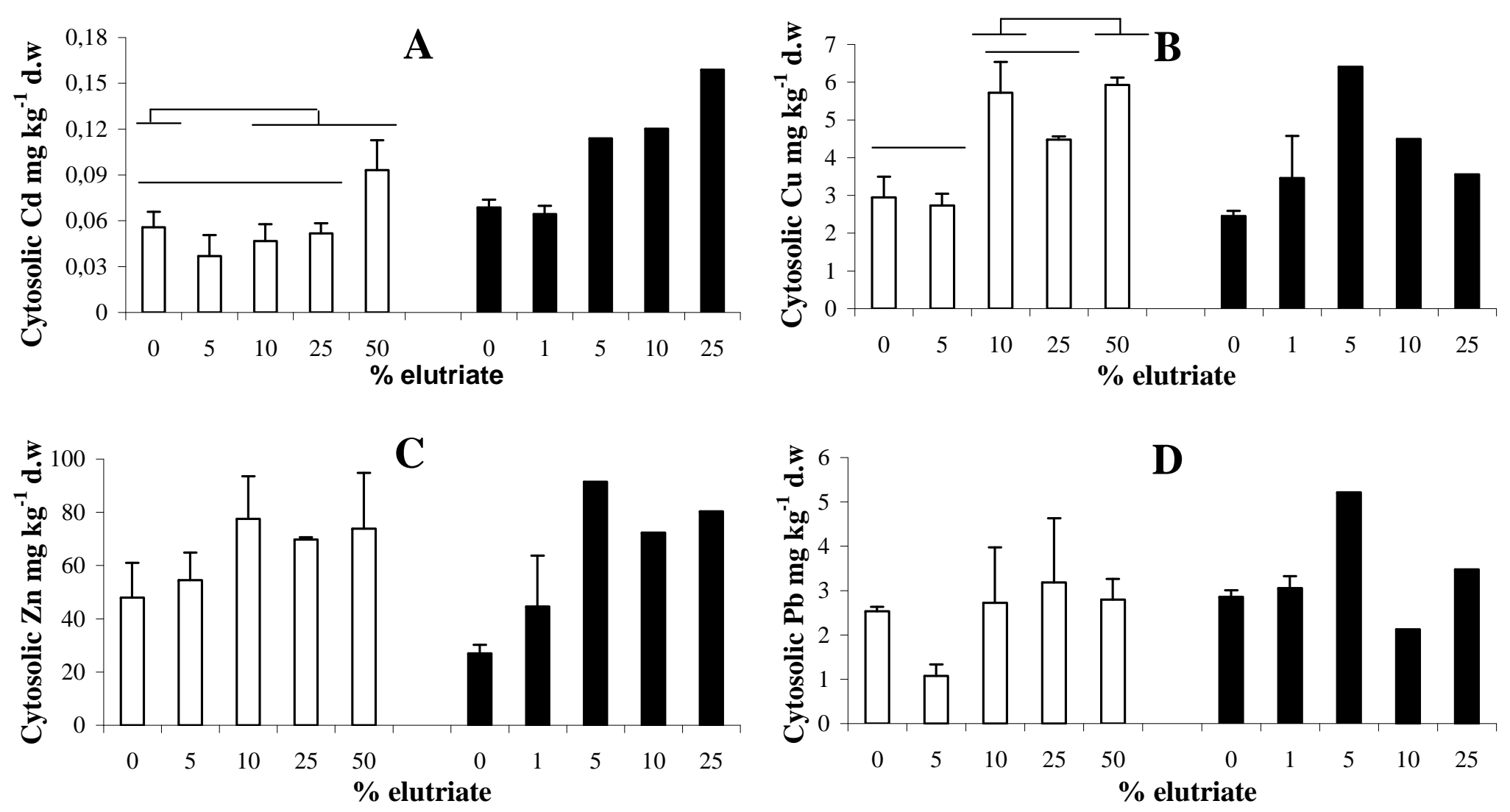

Figure 4. Cytosolic metal concentrations (mean \pm SD, three replications) in larvae after 10 days (Bidassoa, white bars) or 7 days (Dunkerque, black bars; except at $25 \%$ only 5 days) of exposure to different elutriate concentrations. $\mathrm{A}, \mathrm{Cd} ; \mathrm{B}, \mathrm{Cu} ; \mathrm{C}, \mathrm{Zn}$ and $\mathrm{D}, \mathrm{Pb}$. For statistical comparison presentation, see Figure 2 legend. 
Figure 5
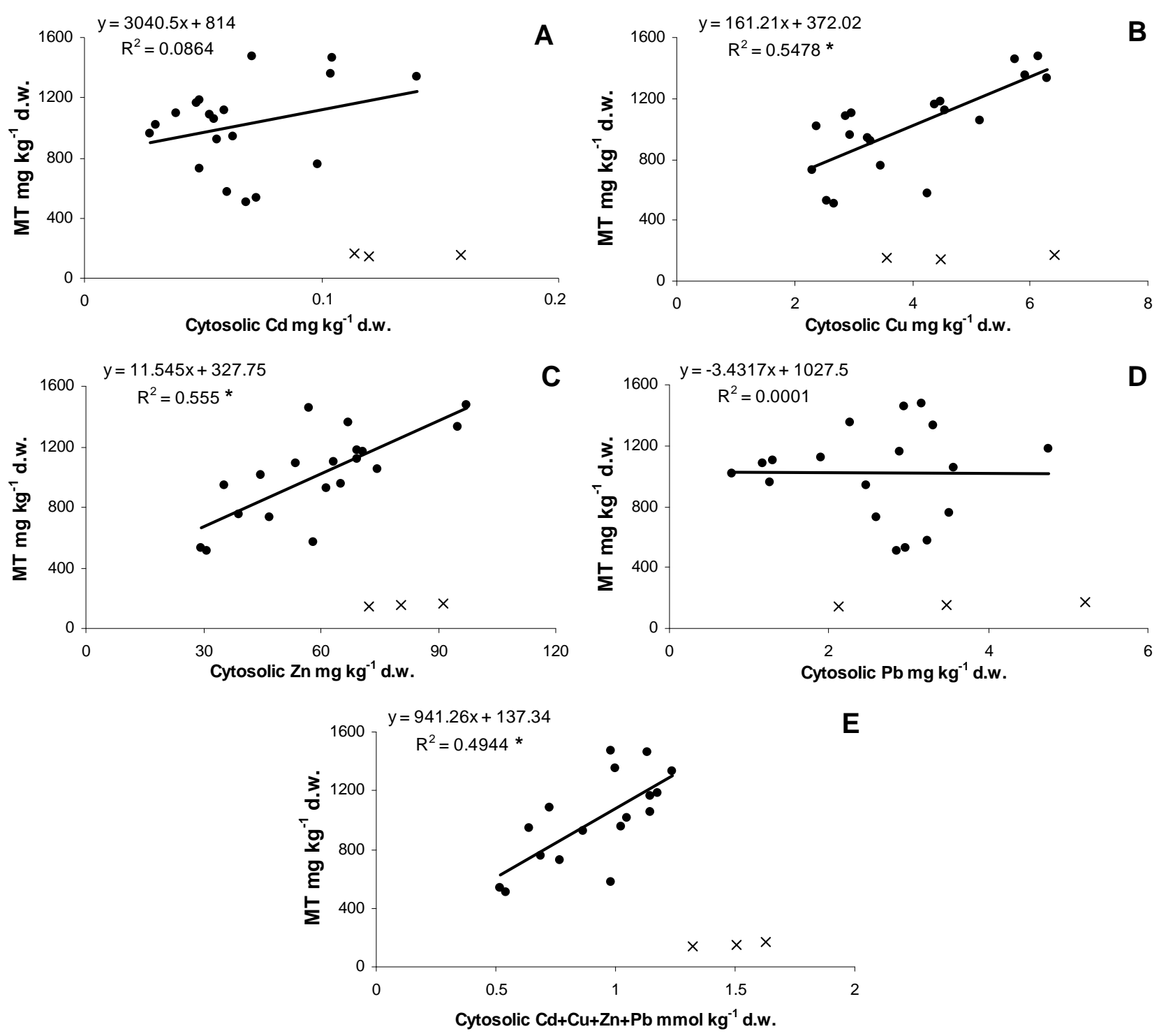

Figure 5 Relationships between cytosolic (S1) metal (individual or combined) and MT concentrations in whole larva categories $(A, C d ; B, C u ; C, Z n ; D, P b$ and $E, C d+C u+Z n+P b)$. The linear regression take into account all the larvae excepted those showing dramatic biological effects (larvae exposed to 5,10 or $25 \%$ Dunkerque elutriate as indicated by an $\mathrm{x}$ ). Significant correlations (at $95 \%$ level) are indicated with an asterisk. 
Tables

Table 1.

\begin{tabular}{cccccc}
\hline & Site & $\mathrm{Cd}$ & $\mathrm{Cu}$ & $\mathrm{Zn}$ & $\mathrm{Pb}$ \\
\hline Sediment & Dunkerque & $2.2(0.05)$ & $158(10)$ & $542(36)$ & $391(24)$ \\
& Bidassoa & $0.8(0.1)$ & $70(11)$ & $268(31)$ & $74(9)$ \\
\hline Filtered & & $0.009(0.001)$ & $0.7(0.2)$ & $2(0.5)$ & $0.7(0.2)$ \\
seawater & & & & & \\
\hline Raw elutriate & Dunkerque & $0.05(0.01)$ & $5(1.1)$ & $21.5(4)$ & $12.3(2)$ \\
& Bidassoa & $0.10(0.03)$ & $10.6(3.3)$ & $25.3(5.3)$ & $8.3(2.7)$ \\
& & & & & \\
\hline
\end{tabular}

Table 1. Heavy metal contents in Dunkerque and Bidassoa sediments $\left(\mu \mathrm{g} \mathrm{g}^{-1}\right.$ dry weight, mean and SD between brackets), raw elutriates obtained from these sediments and control seawater $\left(\mu \mathrm{g} \mathrm{L}^{-1}\right)$ used to extract and dilute these raw elutriates to obtain the different exposure media.

Table 2.

\begin{tabular}{lcccccccccc}
\hline & $\mathrm{PCB}^{\mathrm{a}}$ & $\mathrm{As}$ & $\mathrm{Cd}$ & $\mathrm{Cr}$ & $\mathrm{Cu}$ & $\mathrm{Hg}$ & $\mathrm{Ni}$ & $\mathrm{Pb}$ & $\mathrm{Zn}$ \\
\hline Géode background & 0 & 4.4 & 0.5 & 45 & 35 & 0.2 & 20 & 47 & 115 \\
Géode median & 0.00025 & 12.5 & 0.6 & 45 & 22.5 & 0.2 & 18.5 & 50 & 138 \\
& & & & & & & & & \\
\hline${ }^{a}$ PCB = polychlorinated biphenyl & & & & & & & &
\end{tabular}

Table 2: French "Géode" classification of sediment quality. Géode background denotes mean PCB and metal contamination level $\left(\mu \mathrm{g} \mathrm{g}^{-1}\right.$ dry weight) of sediments collected from reference and uncontaminated areas. Géode median (Md) is calculated on the basis of sediments taken in various harbours in France. 
Table 3.

\begin{tabular}{ccccccc}
\hline Site & $0 \%$ & $1 \%$ & $5 \%$ & $10 \%$ & $25 \%$ & $50 \%$ \\
\hline Bidassoa & $0.52(0.10)$ & nd & 0.68 & $0.44(0.31)$ & 0.50 & $0.46(0.08)$ \\
& & & $(0.09)$ & & $(0.17)$ & \\
\hline Dunkerque & $0.39(0.006)$ & $0.24^{\star}$ & $0.16^{\star}$ & $0.23^{\star}$ & nd & nd \\
& & $(0.02)$ & $(0.0008)$ & $(0.006)$ & & \\
\hline
\end{tabular}

Table 3. Condition index $(\mathrm{Cl}$, mean; \pm SD between bracket) of larvae recovered after 10 (Bidassoa) or 7 (Dunkerque) days of rearing in medium containing different percentage of elutriate. No $\mathrm{Cl}$ was calculate in the case of $25 \%$ of Dunkerque elutriate because rearing was stopped after 5 days * indicate a significant difference at $95 \%$ level of the $\mathrm{Cl}$ compare to the control $(0 \%)$ for each sediment tested. nd: no data. 